\title{
Statistical analyses of groundwater chemistry in the Qingdong coalmine, northern Anhui province, China: implications for water-rock interaction and water source identification
}

\author{
Kai Chen ${ }^{1,2} \cdot$ Linhua Sun ${ }^{1,2} \cdot$ Jiying $\mathrm{Xu}^{1,3}$
}

Received: 4 July 2018 / Accepted: 1 February 2021 / Published online: 17 February 2021

(C) The Author(s) 2021

\begin{abstract}
Hydrochemistry of groundwater is important in coal mines because it can be used for understanding water-rock interaction and inrush water source identification. In this study, major ion concentrations of groundwater samples from the loose layer aquifer (LA), coal-bearing aquifer (CA) and Taiyuan Formation limestone aquifer (TA) in the Qingdong coal mine, northern Anhui province, China, have been analyzed by a series of statistical methods for identifying the source of chemical constituents in groundwater and the source of inrush water. The results indicate that the mean concentration of the major ions in the LA were ordered as follows: $\mathrm{HCO}_{3}{ }^{-}>\mathrm{SO}_{4}{ }^{2-}>\mathrm{Na}^{+}+\mathrm{K}^{+}>\mathrm{Cl}^{-}>\mathrm{Ca}^{2+}>\mathrm{Mg}^{2+}>\mathrm{CO}_{3}{ }^{2-}$, whereas average values of the $\mathrm{CA}$ in decreasing order are $\mathrm{SO}_{4}{ }^{2-}, \mathrm{Na}^{+}+\mathrm{K}^{+}, \mathrm{HCO}_{3}{ }^{-}, \mathrm{Cl}^{-}, \mathrm{Ca}^{2+}, \mathrm{Mg}^{2+}$ and $\mathrm{CO}_{3}{ }^{2-}$, and the major ion concentrations of the TA have the following order: $\mathrm{SO}_{4}{ }^{2-}>\mathrm{Na}^{+}+\mathrm{K}^{+}>\mathrm{Ca}^{2+}>\mathrm{HCO}_{3}{ }^{-}>\mathrm{Cl}^{-}>\mathrm{Mg}^{2+}>\mathrm{CO}_{3}{ }^{2-}$, and most of the samples are $\mathrm{Na}-\mathrm{SO}_{4}$ and $\mathrm{Ca}-\mathrm{SO}_{4}$ types. TDS content in water increases with aquifer depth, whereas the $\mathrm{pH}$ values ranged from 7.1 to 8.9, indicating a weak alkaline environment. Two sources (weathering of silicate minerals and dissolution of evaporate minerals) have been identified by principal component analysis responsible for the chemical variations of the groundwater, and their contribution ratios have been quantified by Unmix model. Moreover, based on the Q-mode cluster and discriminant analyses, the samples with known sources have been identified correctly to be $95.7 \%$ and $97.6 \%$, respectively, and the samples with unknown sources have been determined with high probability (78-100\%).
\end{abstract}

Keywords Groundwater $\cdot$ Hydrochemistry $\cdot$ Water-rock interaction $\cdot$ Water inrush $\cdot$ Coalmine

\section{Introduction}

Coal is a primary source of energy to China, and this situation will last for decades in the future. However, just because of the high production of coal, a series of disasters have occurred in the process of coal mining. Previous studies revealed that five kinds of disasters (water, fire, gas, dust and roof) have brought to mankind, huge economic losses or the death of people (Wu et al. 2013), and the reasons have

Linhua Sun

sunlinh@126.com

1 School of Resources and Civil Engineering, Suzhou University, Anhui 234000, China

2 School of Earth and Environment, Anhui University of Science and Technology, Anhui 232001, China

3 National Engineering Research Center of Coal Mine Water Hazard Controlling, Anhui 234000, China been attributed to be the complicated geological conditions, the imperfect mining technology or, the subjective neglect of the management.

In response to this situation, two types of strategies have been applied for the prevention of water inrush in coalmines: (1) the active one, which means to predict the possibility of water inrush based on the understanding of the hydrogeological conditions of the coal mine; (2) the passive one, which means to do something to minimize the loss after the water inrush (e.g., draining out of the water and recovering coal production) ( $\mathrm{Xu}$ and $\mathrm{Bu} 2015$ ).

Except for the man-made factors, a series of natural factors have been identified responsible for the occurrence of water inrush accident in coal mines: e.g., the quantity of water in the aquifers, the channel for water flow, the hydro-connection between aquifers and the thickness of the water resisting layer (Gui and Chen 2007). And therefore, understanding the hydrological condition of the coalmine before the water inrush is the most fundamental work for 
the prevention of water inrush-related accidents in coalmines, and getting the reliable information about the source of inrush water is the most important work after water inrush.

Groundwater in the aquifers contains a series of information, including the water level, quantity, temperature, velocity, turbidity and hydrochemistry, among others (Gui and Chen 2007), which provides the possibility of the water source identification among different aquifers, and a large number of methods have been proposed (Liu et al. 2018; Shi et al. 2018; Wu et al. 2019; Wang et al. 2020). For example, the mixing ratio of water inrush sources in the Qidong coal mine, Anhui province, China, has been calculated by factor analysis, and results provide theoretical guidance for the prevention and control of water disasters (Sun and Gui 2015). Moreover, the source of inrush water had been identified by means of Q-model and principal component analysis in Zhaizhen coal mine, Shandong Province, China (Wang and Shi 2019). These studies confirmed that statistical analysis of groundwater chemistry is effective for identifying the inrush water sources in coal mines.

Roofing, gas, dust and other hazards have been fully studied in the Qingdong coal mine, northern Anhui province, China, but the source of inrush water has not received corresponding attention, which is a potential threat to coal production (Liu et al. 2017; Si et al. 2018). Therefore, in this study, forty-six groundwater samples have been collected from the representative aquifer systems in the Qingdong coal mine, and a series of statistical methods (including principal component, cluster and discriminant analysis, as well as the analysis of the Unmix model) have been applied to their major ion concentrations, for getting the information about: (1) identifying the different types of water-rock interactions for determining the chemical compositions of the groundwater; (2) quantifying the contributions of different types of water-rock interactions and (3) establish the water source identification model for the coalmine.

\section{Materials and methods}

\section{Study area}

The coalfield in the northern Anhui province is an important energy base in China with annual output of coal over 100 million tons. The Qingdong coalmine is one of the thirty coalmines in the region. It is situated $45 \mathrm{~km}$ west to the Suzhou City, northern Anhui Province, China (Fig. 1), and the location of the coalmine is $116^{\circ} 25^{\prime} 44^{\prime \prime}-116^{\circ} 34^{\prime} 44^{\prime \prime}$ (longitude) and 33 $36^{\prime} 34^{\prime \prime}-33^{\circ} 40^{\prime} 29^{\prime \prime}$ (latitude). The study area belongs to the monsoon warm temperate semi-humid climate, with an average temperature of $14.6^{\circ} \mathrm{C}$ over the years. The average annual precipitation is $811.8 \mathrm{~mm}$, and

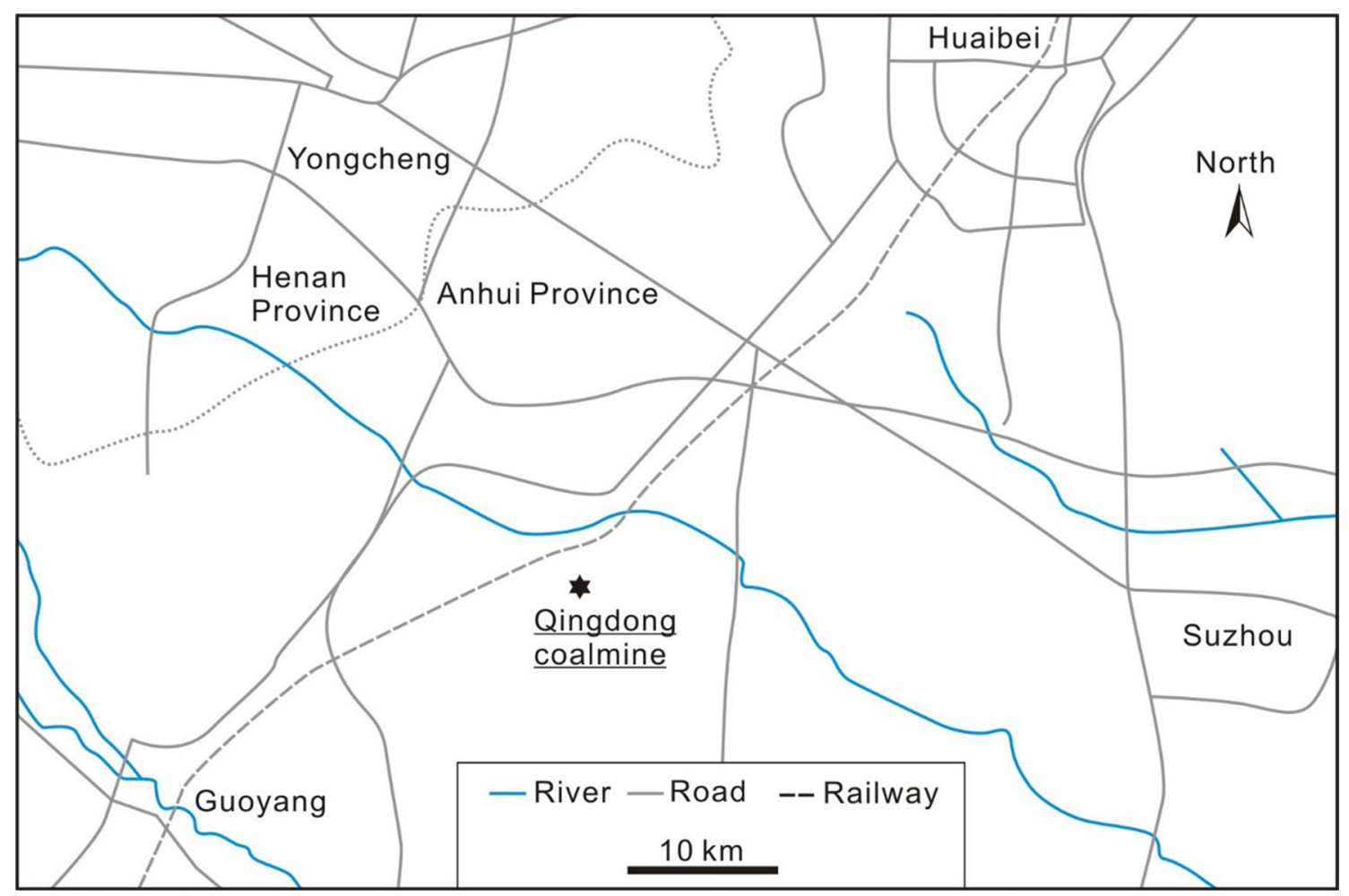

Fig. 1 Location of the Qingdong coal mine 
the rainfall is mainly concentrated in July and August. The length of the mine is $3.5-6.5 \mathrm{~km}$ from south to north, and the width is $13 \mathrm{~km}$ from east to west, the total area of the mine is $51.7 \mathrm{~km}^{2}$.

The aquifer in the study area from shallow to deep can be divided into four systems: loose layer (LA), coal-bearing sandstone (CA), Taiyuan Formation limestone (TA) and Ordovician limestone (OA). Details of the four aquifer systems are as follows.

LA: The coalmine is covered by the loose layer sediments, including the Tertiary and Quaternary, the average thickness of the Tertiary and Quaternary are $154 \mathrm{~m}$ and $92 \mathrm{~m}$, respectively. The main rock types in the LA including clay, sandy clay and calcareous clay. Multi-layer composite structure is observed in the loose layer, and four secondary aquifers were further identified. In these four aquifers, the fourth aquifer is highly water-rich and can be recharged from rainfall. Therefore, the water in the fourth aquifer is a threat for the safety of coal mining due to direct contact with the coal-bearing strata.

CA: Permian is the main coal-bearing strata in the area, and the main constituent in CA including mudstone, siltstone, sandstone (mainly feldspathic quartz sandstone) and coal seams, and three secondary aquifers can be subdivided. The water in this aquifer is stored primarily in sandstone fractures. In recent years, mining activities have disrupted the integrity of the formation and altered the original runoff environment, resulting in water being able to enter the coal mining tunnel by infiltration. The water in the crack of sandstone is the main threat.

TA and OA: Comparatively, the primary rock type in the TA and OA is limestone, to a lesser extent, the mudstone and sandstone. These two aquifers are highly water-rich, with high water pressure and poor runoff conditions without human activities. Therefore, the water in the karst cave is also a threat to the safety of coal mining. In summary, the water from the fourth aquifer, the crack of the sandstone and the karst cave of the limestone threaten the safety of coal mining activities, which is similar to the Renlou coal mine in the similar hydrological unit (Sun 2013).

\section{Sampling and analysis}

Forty-six groundwater samples were collected from four representative aquifer systems in the Qingdong coal mine: 7 from the LA, 16 from the CA, and 19 from the TA. LA samples were extracted from the wells using a pump, CA samples were collected directly in the coal mining tunnel and TA samples were collected from boreholes. Other four samples (UN1 and 2 were from the boreholes of the CA, and the UN3 and 4 were from the boreholes of the TA), have been defined as unknown source samples for verifying the effect of water source identification. The contents of the physico-chemical parameters and major ions in the water samples were measured as follows.

$\mathrm{pH}$ values were measured by a portable water analyzer with an accuracy of 0.01 . TDS values were calculated by subtracting 0.5 times bicarbonate from the sum of all ion concentrations (Unit: $\mathrm{mg} / \mathrm{L}$ ). Concentrations of eight kinds of major ions $\left(\mathrm{Na}^{+}, \mathrm{K}^{+}, \mathrm{Ca}^{2+}, \mathrm{Mg}^{2+}, \mathrm{Cl}^{-}, \mathrm{SO}_{4}{ }^{2-}, \mathrm{HCO}_{3}^{-}\right.$and $\mathrm{CO}_{3}{ }^{2-}$ ) were analyzed in this study: $\mathrm{Na}^{+}, \mathrm{K}^{+}, \mathrm{Ca}^{2+}, \mathrm{Mg}^{2+}$, $\mathrm{Cl}^{-}$and $\mathrm{SO}_{4}{ }^{2-}$ were analyzed by ion chromatography, whereas the $\mathrm{HCO}_{3}{ }^{-}$and $\mathrm{CO}_{3}{ }^{2-}$ were analyzed by acid-base titration. Due to the low concentrations of $\mathrm{K}^{+}, \mathrm{Na}^{+}$and $\mathrm{K}^{+}$ were merged and presented as $\left(\mathrm{Na}^{+}+\mathrm{K}^{+}\right)$. All of the analyses were conducted in the Engineering and Technological Research Center of Coal Exploration, Anhui Province, China.

After all ion concentration tests are completed, the AE (analytical errors) were checked by calculating the mass balance using the following formula.

$A E=100 *\left(\frac{m e q / L, \text { cations }- \text { meq } / L, \text { anions }}{\text { meq } / L, \text { cations }+ \text { meq } / L, \text { anions }}\right)$

With the exception of one water sample, which had an AE of $12 \%$, the AEs of all other water samples were within $-5 \%$ to $+5 \%$, indicating that the results of the analyses were reasonable and credible (Nordstrom et al. 1989).

\section{Statistical analyses}

In this study, a series of statistical methods were applied to the hydrochemical data of the groundwater: (1) For getting the information about the water-rock interaction (mainly the source of major ions), the factor analysis was applied for getting qualitative information about the source of the major ions, whereas the US EPA (US Environmental Protection Agency) Unmix model was applied for getting quantitative information. (2) For the water source identification, cluster and discriminant analyses were applied along with the method related to the source contributions generated by the Unmix model. Detailed descriptions of these statistical methods are contained in the following text.

1. Correlation analysis: a multivariate statistical analysis method that can be used to evaluate the degree of correlation between two variables at significance levels. Previous studies have confirmed that two or more elements of significant correlation usually come from similar origins or are controlled by the same processes (Sunkari and Abu 2019; Zango et al. 2019).

2. Principal component analysis: an important statistical method that is not only used to simplify and classify the data, but also is used to find the most important variables in the data. During geochemical studies, factor analy- 
sis has long been used to track the sources of element (Yidana et al. 2018; Wang and Shi 2019; Gubran et al. 2019; Ramaroson et al. 2020).

3. Cluster analysis: it is a multivariate method applied to find the true groups of data or stations. In clustering, the objects are grouped in order to divide the similar objects into the same class. The method has been applied to the hydrochemical studies for a long time (Tay et al. 2015; Bencer et al. 2016; Chen et al. 2020).

4. Discriminant analysis: it uses linear or quadratic functions of the variables that are "best" divided into two or more predefined groups in a separate case. It is a simple and effective tool for the establishment of the inrush water source identification model (Sun and Gui 2015).

5. Unmix model analysis: it is a mathematical receptor model used for quantifying the sources of contaminants (Lang and Yang 2014; Liu and Sun 2015; Jain et al. 2018; Zhang et al. 2019). The source types are identified by comparing them to measured profiles, whereas the source contributions are used to determine how much each source contributed to a sample. The basic idea of the model is $C_{m}=\sum X_{1} \times S_{1}+X_{2} \times S_{2} \ldots X_{n} \times S_{n}$. Where $C_{m}$ is the measured concentration of sample, $S_{n}$ is the profile contributed by any types of sources, $X_{n}$ is the portion of $\mathrm{Sn}$, and $\left(X_{n} \times S_{n}\right) / \sum\left(X_{n} \times S_{n}\right)$ is the contribution of source $\mathrm{n}$ for the $C_{m}$. The hydrochemistry of the groundwater is also a multi-source contribution issue, the different types of water-rock interactions can be considered as sources, whereas the degrees of waterrock interaction can be considered as contributions.

Moreover, Unmix model analysis was performed by EPA Unmix software (version 6.0), and RStudio software (Team, Core R 2013) was employed to conduct the correlation analysis, principal component analysis, cluster analysis and discriminant analysis.

\section{Results and discussion}

\section{Hydrochemistry}

Major ion concentrations of the groundwater samples from the different aquifer systems are shown in Table 1 and Fig. 2. As shown in Table 1, the mean concentration of the major ions in the LA were ordered as follows: $\mathrm{HCO}_{3}{ }^{-}(370 \mathrm{mg} / \mathrm{L})>\mathrm{SO}_{4}{ }^{2-}(275 \mathrm{mg} / \mathrm{L})>\mathrm{Na}^{+}+\mathrm{K}^{+}$ $(223 \mathrm{mg} / \mathrm{L})>\mathrm{Cl}^{-}(97 \mathrm{mg} / \mathrm{L})>\mathrm{Ca}^{2+}(39 \mathrm{mg} / \mathrm{L})>\mathrm{Mg}^{2+}$ $(38 \mathrm{mg} / \mathrm{L})>\mathrm{CO}_{3}{ }^{2-}(21 \mathrm{mg} / \mathrm{L})$, whereas average values of the CA in decreasing order are $\mathrm{SO}_{4}{ }^{2-}(1000 \mathrm{mg} / \mathrm{L})$, $\mathrm{Na}^{+}+\mathrm{K}^{+}(647 \mathrm{mg} / \mathrm{L}), \mathrm{HCO}_{3}{ }^{-}(334 \mathrm{mg} / \mathrm{L}), \mathrm{Cl}^{-}(184 \mathrm{mg} / \mathrm{L})$, $\mathrm{Ca}^{2+}(46 \mathrm{mg} / \mathrm{L}), \mathrm{Mg}^{2+}(23 \mathrm{mg} / \mathrm{L})$ and $\mathrm{CO}_{3}{ }^{2-}(17 \mathrm{mg} / \mathrm{L})$, and the major ion concentrations of the TA have the following order: $\mathrm{SO}_{4}{ }^{2-}(1556 \mathrm{mg} / \mathrm{L})>\mathrm{Na}^{+}+\mathrm{K}^{+}(384 \mathrm{mg} / \mathrm{L})>\mathrm{Ca}^{2+}$ $(321 \mathrm{mg} / \mathrm{L})>\mathrm{HCO}_{3}{ }^{-}(258 \mathrm{mg} / \mathrm{L})>\mathrm{Cl}^{-}(225 \mathrm{mg} / \mathrm{L})>\mathrm{Mg}^{2+}$ $(133 \mathrm{mg} / \mathrm{L})>\mathrm{CO}_{3}{ }^{2-}(1 \mathrm{mg} / \mathrm{L})$.

As can be seen from Fig. 2, the $\mathrm{Na}^{+}+\mathrm{K}^{+}, \mathrm{Cl}^{-}$and $\mathrm{SO}_{4}{ }^{2-}$ contents of groundwater from the three aquifers were significantly different ( $p<0.05$, Fig. $2 a, d$ and e), and the LA and CA samples had similar concentrations of $\mathrm{Ca}^{2+}, \mathrm{Mg}^{2+}$ and $\mathrm{HCO}_{3}^{-}(p<0.05$, Fig. 2b, c and f). In general, the groundwater samples from the $\mathrm{CA}$ have the highest mean concentrations of $\mathrm{Na}^{+}+\mathrm{K}^{+}(647 \mathrm{mg} / \mathrm{l})$ compared with other two aquifer systems, whereas the groundwater samples from the TA have highest mean concentrations of $\mathrm{Ca}^{2+}(321 \mathrm{mg} / \mathrm{l}), \mathrm{Mg}^{2+}(133 \mathrm{mg} / \mathrm{l})$, $\mathrm{Cl}^{-}(225 \mathrm{mg} / \mathrm{l})$, and $\mathrm{SO}_{4}{ }^{2-}(1556 \mathrm{mg} / \mathrm{l})$ and the groundwater samples from the LA have highest mean concentrations of $\mathrm{HCO}_{3}{ }^{-}(370 \mathrm{mg} / \mathrm{l})$ (Table 1). In common, the major ion concentrations in groundwater are closely related to the types of surrounding rock. Therefore, high content of $\mathrm{Na}^{+}+\mathrm{K}^{+}$in CA samples are associated with weathering of silicates, while high $\mathrm{Ca}^{2+}$ and $\mathrm{Mg}^{2+}$ contents in TA samples are associated with dissolution of carbonates and sulfates. Moreover, from shallow to deep, the concentration of $\mathrm{HCO}_{3}{ }^{-}$in groundwater shows a decreasing trend, while the concentrations of $\mathrm{SO}_{4}{ }^{2-}$ and $\mathrm{Cl}^{-}$have an increasing trend, implying poor runoff conditions for $\mathrm{CA}$ and $\mathrm{TA}$.
Table 1 Major ion concentrations $(\mathrm{mg} / \mathrm{L})$ of the groundwater samples

\begin{tabular}{llllllllll}
\hline Aquifer & $\mathrm{Na}^{+}+\mathrm{K}^{+}$ & $\mathrm{Ca}^{2+}$ & $\mathrm{Mg}^{2+}$ & $\mathrm{Cl}^{-}$ & $\mathrm{SO}_{4}^{2-}$ & $\mathrm{HCO}_{3}^{-}$ & $\mathrm{CO}_{3}^{2-}$ & $\mathrm{pH}$ & $\mathrm{TDS}$ \\
\hline $\mathrm{LA}$ & $157-265$ & $3-72$ & $11-65$ & $24-161$ & $100-427$ & $7-729$ & $0-76$ & $7.2-9.1$ & $689-1106$ \\
$(n=7)$ & $(223)$ & $(39)$ & $(38)$ & $(97)$ & $(275)$ & $(370)$ & $(21)$ & $(8.1)$ & $(884)$ \\
$\mathrm{CA}$ & 326,799 & $11-119$ & $5-61$ & $83-233$ & $381-1333$ & $191-525$ & $0-98$ & $7.7-8.9$ & $1105-2649$ \\
$(n=16)$ & $(647)$ & $(46)$ & $(23)$ & $(184)$ & $(1000)$ & $(334)$ & $(17)$ & $(8.3)$ & $(2081)$ \\
$\mathrm{TA}$ & $281-566$ & $196-553$ & $77-193$ & $108-283$ & $1255-2064$ & $188-317$ & $0-14$ & $7.1-8.5$ & $2322-3524$ \\
$(n=19)$ & $(384)$ & $(321)$ & $(133)$ & $(225)$ & $(1556)$ & $(258)$ & $(1)$ & $(7.7)$ & $(2751)$ \\
$\mathrm{UN}$ & $386-697$ & $56-433$ & $26-337$ & $89-205$ & $1115-3123$ & $151-293$ & $0-14$ & $7.7-8.3$ & $2077-4557$ \\
$(n=4)$ & $(534)$ & $(208)$ & $(144)$ & $(145)$ & $(1809)$ & $(232)$ & $(5)$ & $(7.9)$ & $(2948)$ \\
\hline
\end{tabular}



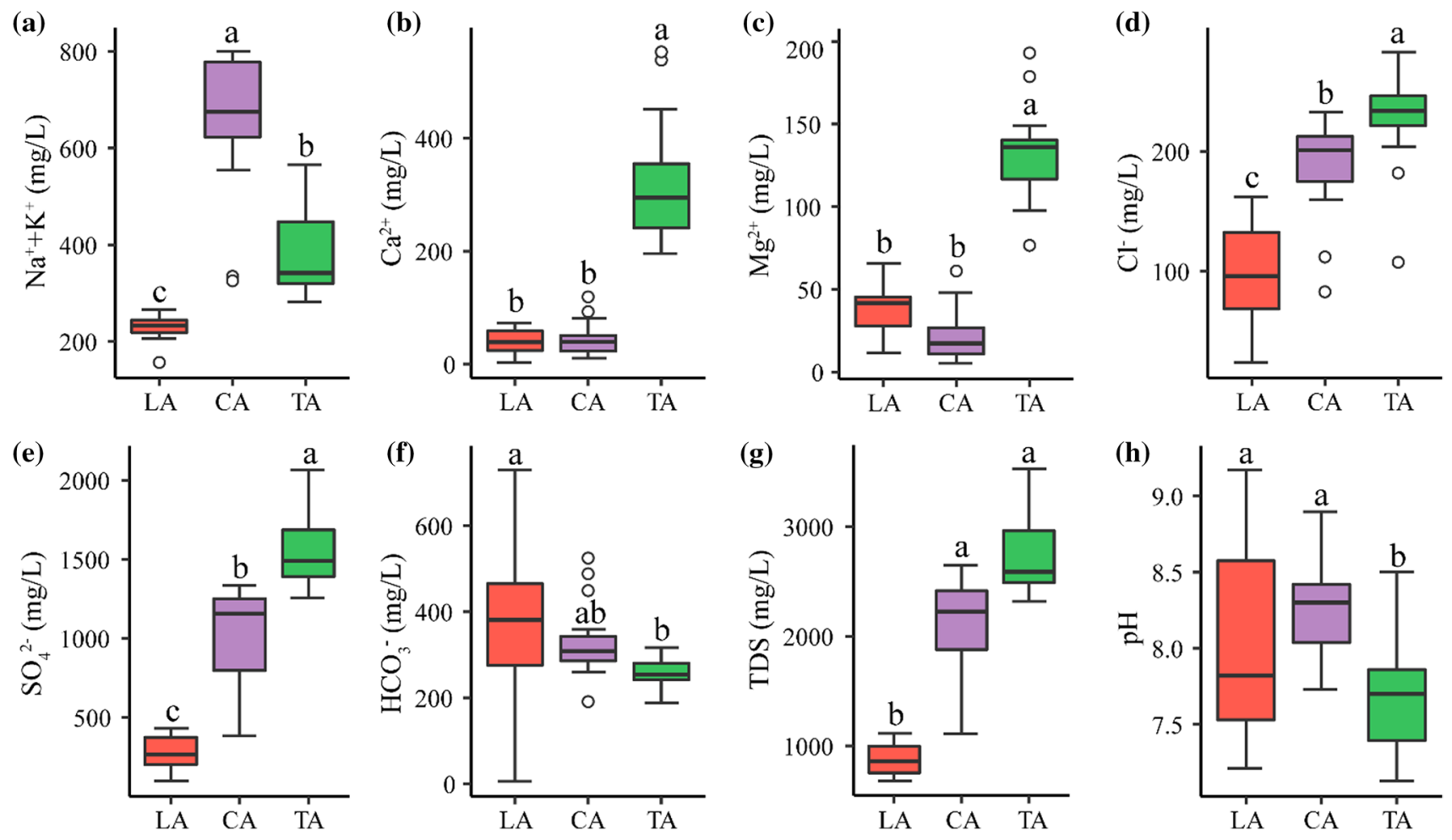

Fig. 2 Box plot of major ions and physico-chemical parameters contents of groundwater samples in different aquifers

As shown in Fig. $2 \mathrm{~g}$ and $\mathrm{h}$, the average TDS content in groundwater of LA, CA and TA increased from $884 \mathrm{mg} / \mathrm{L}$, $2081 \mathrm{mg} / \mathrm{L}$ to $2751 \mathrm{mg} / \mathrm{L}$, which means that the degree of water-rock interaction deepens with increasing aquifer depth, and the $\mathrm{pH}$ values ranged from 7.1 to 8.9 , indicating a weak alkaline environment.

During the groundwater flows from the recharge to the discharge zone, the hydrochemical types will change from $\mathrm{HCO}_{3}{ }^{-}, \mathrm{SO}_{4}{ }^{2-}$ to $\mathrm{Cl}^{-}$(Tóth, 1999). And therefore, the classification of the hydrochemcial types is important for the understanding of the hydrological evolution of the groundwater system. Classification of groundwater in this study is based on the concentration of cations and anions by using the Piper diagram, and the results are shown in Fig. 3. The results indicate that $\mathrm{Na}-\mathrm{SO}_{4}$ type is the most popular one, which occupies $71 \%$ of the LA, $100 \%$ of the CA and $42 \%$ of the TA samples, respectively. Moreover, the rest of the LA samples are $\mathrm{Na}-\mathrm{HCO}_{3}$ type (29\%), and the $47 \%$ and $11 \%$ of the CA groundwater samples are classified as $\mathrm{Ca}-\mathrm{SO}_{4}$ and $\mathrm{Mg}-\mathrm{SO}_{4}$ types, respectively. Comparatively, the UN1 and UN2 groundwater samples are classified into $\mathrm{Na}-\mathrm{SO}_{4}$ types, whereas the UN3 and $\mathrm{UN} 4$ groundwater samples are classified into $\mathrm{Mg}-\mathrm{SO}_{4}$ and Na-SO $\mathrm{S}_{4}$ types. It can also be noticed from Fig. 3 that the $\mathrm{UN} 1$ and 2 samples are similar to the CA samples, whereas the UN3 and 4 samples are similar to the TA samples.

\section{Mechanism controlling groundwater chemistry}

The Gibbs diagram (Gibbs 1970) can be applied to figure out the relationship between the chemical components of groundwater and the lithology from their respective aquifer (Sunkari et al. 2020; Yu et al. 2020). The three factors controlling groundwater chemistry can be classified by the diagram: precipitation, evaporation and water-rock interaction dominance. The formulations of Gibbs are Gibbs $\mathrm{I}=\mathrm{Cl}^{-} /\left(\mathrm{Cl}^{-}+\mathrm{HCO}_{3}^{-}\right)$and Gibbs $\mathrm{II}=\left(\mathrm{Na}^{+}+\mathrm{K}^{+}\right) /$ $\left(\mathrm{Na}^{+}+\mathrm{K}^{+}+\mathrm{Ca}^{2+}\right)$ (unit in meq/l). In this study, Gibbs I values variation ranged from 0.05 to 0.97 and Gibbs II values variation ranged from 0.38 to 0.99 . As can be seen from Fig. 4, all of the samples are located in the water-rock interaction and evaporation dominant areas, which indicated that the water-rock interaction and evaporation have played important roles in the groundwater system for controlling the groundwater chemistry. Meanwhile, from LA to TA, the TDS content in groundwater has an increasing trend, indicating that the degree of water-rock interaction increases with the increase of the aquifer depth.

Weathering of silicate minerals (feldspars), dissolution of halite and cation exchange reaction are generally considered to be the major sources of $\mathrm{Na}^{+}$in groundwater (Zango et al. 2019). As can be seen in Fig. 5a and b, most of the water samples in the three aquifers are above the 1:1 line, 


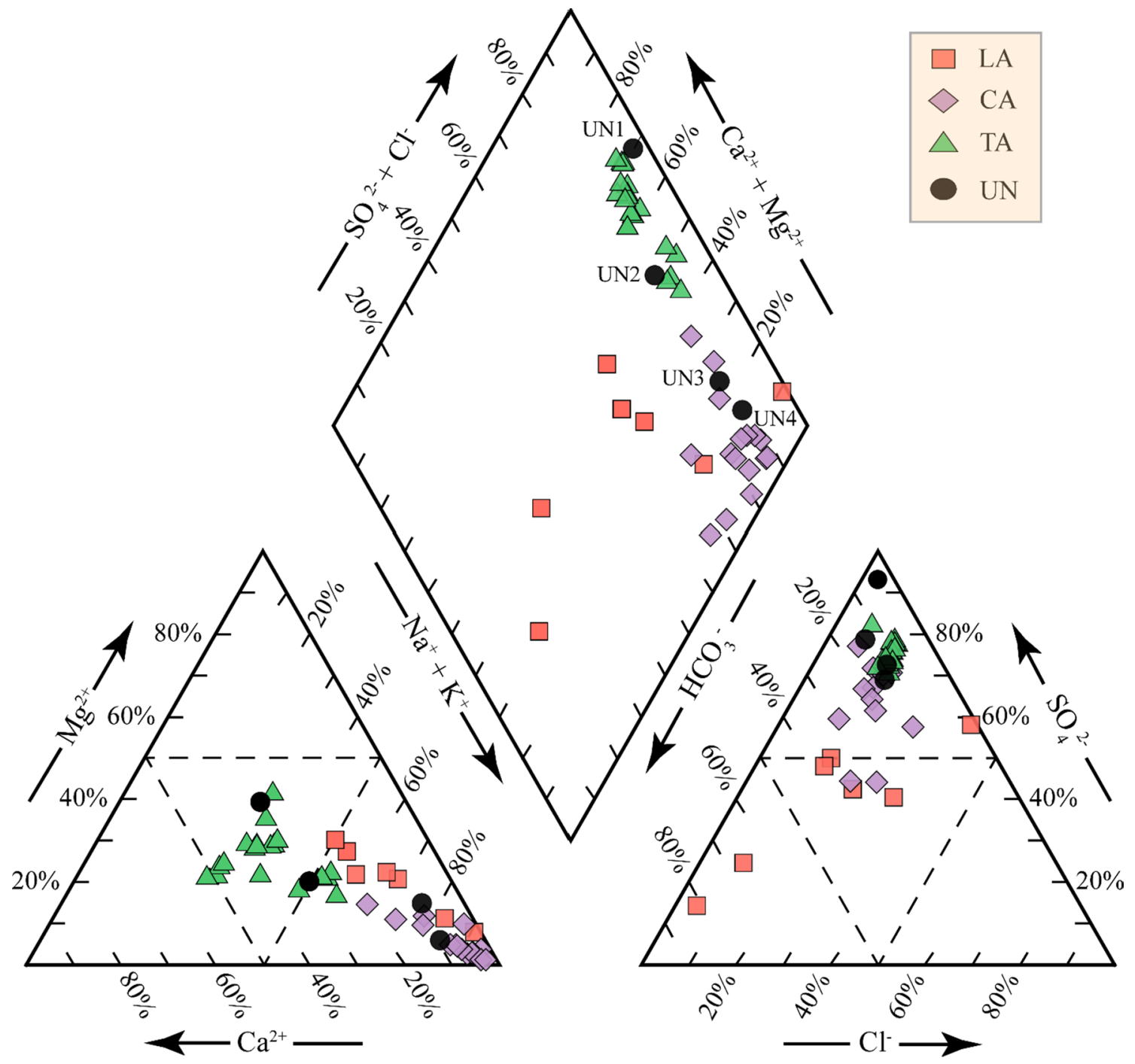

Fig. 3 Piper diagram

which may be related to intense cation exchange reaction, because $\mathrm{Na}^{+}$replacement of $\mathrm{Ca}^{2+}$ and $\mathrm{Mg}^{2+}$ will lead to $\mathrm{Na}^{+}$enrichment in groundwater. $\mathrm{Ca}^{2+}$ and $\mathrm{Mg}^{2+}$ in groundwater are associated with dissolution of carbonate and sulfate and reverse ion exchange. As shown in Fig. 5c, the $\left(\mathrm{Ca}^{2+}+\mathrm{Mg}^{2+}\right) /\left(\mathrm{HCO}_{3}{ }^{-}+\mathrm{SO}_{4}{ }^{2-}\right)$ values in the groundwater of the three aquifers were different, the TA samples were close to the 1:1 line and the concentrations of $\left(\mathrm{Ca}^{2+}+\mathrm{Mg}^{2+}\right)$ and $\left(\mathrm{HCO}_{3}{ }^{-}+\mathrm{SO}_{4}{ }^{2-}\right)$ were significantly higher than those in the LA and CA samples, indicating the influence of carbonate and sulfate dissolution in TA. Moreover, $\left(\mathrm{Ca}^{2+}+\mathrm{Mg}^{2+}\right) /$ $\left(\mathrm{HCO}_{3}{ }^{-}+\mathrm{SO}_{4}{ }^{2-}\right)<1$ in all samples indicates the widespread presence of cation exchange reaction in the three aquifers, especially for CA, which is also consistent with the results of Fig. $5 \mathrm{a}$ and b. $\mathrm{SO}_{4}{ }^{2-}$ in groundwater is usually derived from the dissolution of sulfate minerals and the oxidation of sulfides. The high $\mathrm{SO}_{4}{ }^{2-}$ content in CA samples relative to $\mathrm{Ca}^{2+}$ and $\mathrm{Mg}^{2+}$ was due to the combined effects of ionexchange reaction and oxidation of sulfides (Fig. 5c and d). In the study area, there are a large amount of pyrite in CA, and coal mining activities have led to long-term exposure of the CA to air, which provides favorable conditions for the oxidation of pyrite and then leads to the enrichment of $\mathrm{SO}_{4}{ }^{2-}$ in groundwater $\left(4 \mathrm{FeS}_{2}+13 \mathrm{O}_{2}+2 \mathrm{H}_{2} \mathrm{O} \rightarrow 4 \mathrm{FeSO}_{4}+\right.$ $2 \mathrm{H}_{2} \mathrm{SO}_{4}+2 \mathrm{SO}_{2} \uparrow$ ).

\section{Source of major ions}

\section{Correlation analysis}

In this study, the Spearman correlation method was chosen, which is insensitive to outliers in the data, and the analysis results are shown in Table 2. As shown in Table 2, $\mathrm{Ca}^{2+}$, $\mathrm{Mg}^{2+}, \mathrm{Cl}^{-}$, and $\mathrm{SO}_{4}{ }^{2-}$ have significant positive correlations 

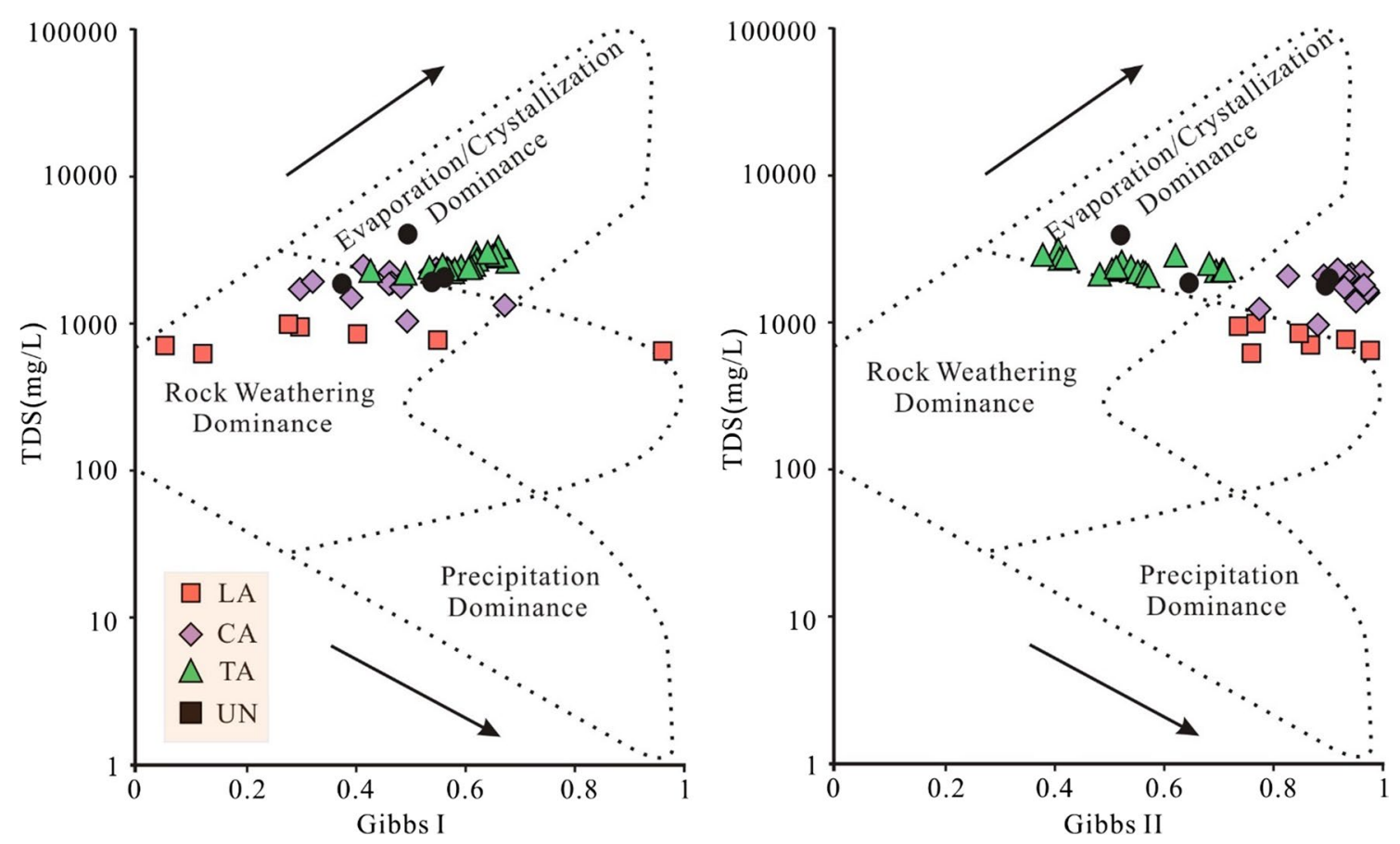

Fig. 4 Gibbs diagrams
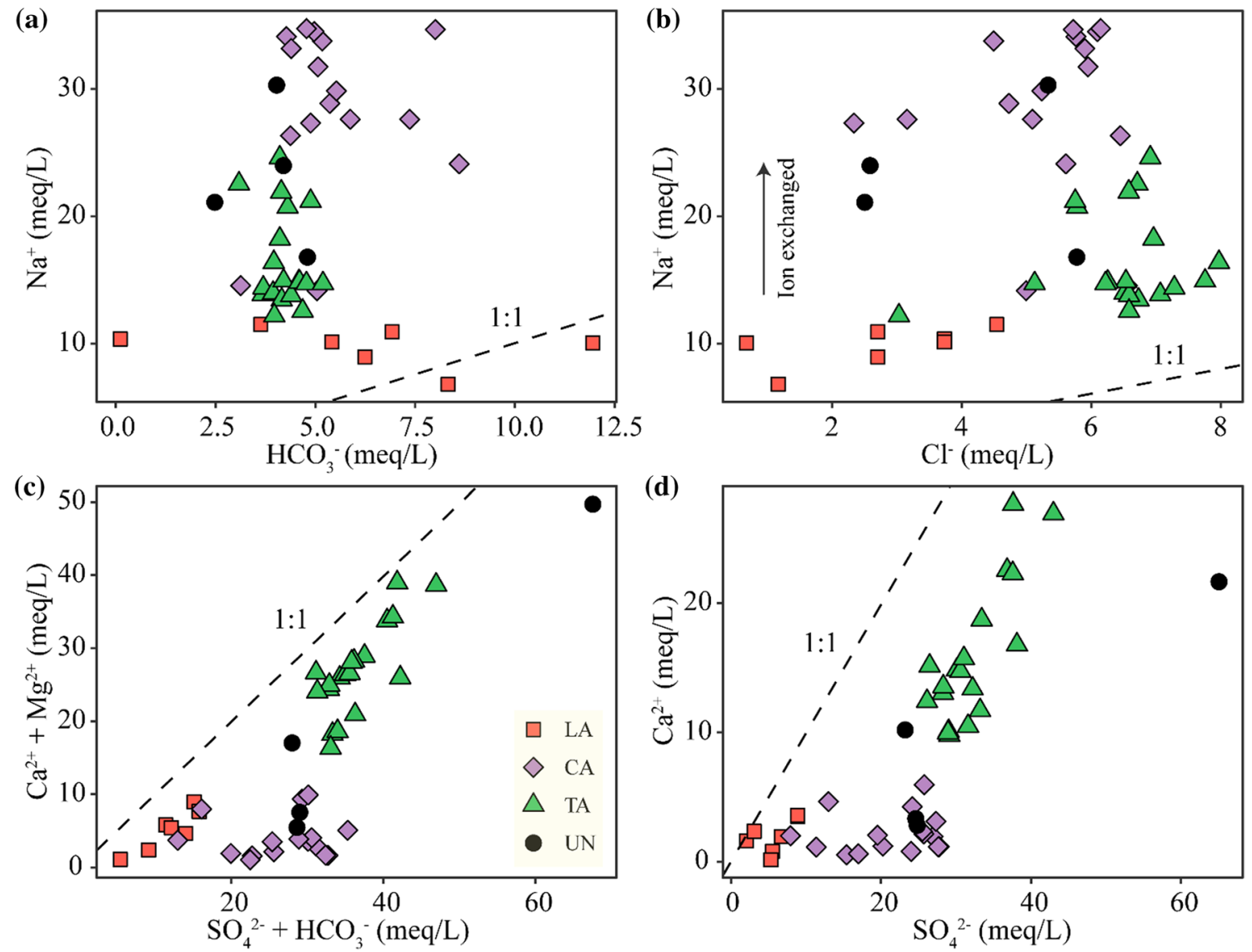

Fig. 5 Major ion relationship in groundwater 
Table 2 Spearman correlation of the major ions in groundwater $(* *$ represent significant correlation at the level of 0.01)

\begin{tabular}{lcccccc}
\hline & $\mathrm{Na}^{+}+\mathrm{K}^{+}$ & $\mathrm{Ca}^{2+}$ & $\mathrm{Mg}^{2+}$ & $\mathrm{Cl}^{-}$ & $\mathrm{SO}_{4}^{2-}$ & $\mathrm{HCO}_{3}^{-}$ \\
\hline $\mathrm{Na}^{+}+\mathrm{K}^{+}$ & 1.000 & & & & & \\
$\mathrm{Ca}^{2+}$ & -0.265 & 1.000 & & & & \\
$\mathrm{Mg}^{2+}$ & $-0.456^{* *}$ & $0.903^{* *}$ & 1.000 & & & \\
$\mathrm{Cl}^{-}$ & 0.088 & $0.657^{* *}$ & $0.397 * *$ & 1.000 & & \\
$\mathrm{SO}_{4}{ }^{2-}$ & 0.152 & $0.804^{* *}$ & $0.690^{* *}$ & $0.698^{* *}$ & 1.000 & \\
$\mathrm{HCO}_{3}^{-}$ & 0.126 & $-0.482^{* *}$ & $-0.437 * *$ & $-0.484^{* *}$ & $-0.564 * *$ & 1.000 \\
\hline
\end{tabular}

** Represent significant correlation at the level of 0.01 with each other, which can be explained by the dissolution of chlorides and sulfate minerals, because they can release $\mathrm{Ca}^{2+}, \mathrm{Mg}^{2+}, \mathrm{Cl}^{-}$and $\mathrm{SO}_{4}{ }^{2-}$ into the water. Furthermore, the significant negative correlation between $\mathrm{Na}^{+}+\mathrm{K}^{+}$and $\mathrm{Mg}^{2+}$ is usually related to the the ion-exchange reaction (Table 2).

\section{Principal component analysis}

In this study, two principal components were obtained based on the initial eigenvalue higher than one, and the results was shown in Table 3 and Fig. 6. As can be seen from the table, the PC1, which accounts for $52.6 \%$ of the total variance explained, has high positive loadings of $\mathrm{Ca}^{2+}, \mathrm{Mg}^{2+}, \mathrm{Cl}^{-}$and $\mathrm{SO}_{4}{ }^{2-}$, but high negative loadings of $\mathrm{HCO}_{3}{ }^{-}$, the second component with $23.6 \%$ of the total variance explained, has high positive loadings of $\mathrm{Na}^{+}+\mathrm{K}^{+}$and negative loadings of $\mathrm{Mg}^{2+}$. Based on the investigations of previous studies, the main processes controlling the groundwater chemistry in the study area include weathering of silicate minerals, ion exchanged reaction, dissolution of carbonate, sulfate and chloride minerals (Sun and Gui 2015). Therefore, the PC2 can be explained to be the weathering of silicate minerals and ion-exchange reaction, which can lead to high concentration of $\mathrm{Na}^{+}+\mathrm{K}^{+}$in water, whereas the $\mathrm{PC} 1$ is related to the dissolution of chlorides and sulfate minerals, because they can release $\mathrm{Ca}^{2+}, \mathrm{Mg}^{2+}, \mathrm{Cl}^{-}$and $\mathrm{SO}_{4}{ }^{2-}$ into the water. It is also observed in Fig. 6 that the groundwater of the three aquifers has significantly different scores on PC1 and PC2 $(p<0.05)$ : the LA samples have the lowest PC1 and PC2 scores, and the CA samples have the highest PC2 scores, whereas the TA samples have the highest PC1 scores. Such a phenomenon indicates that groundwater samples from different aquifer systems have undergone different types and degrees of water-rock interactions: CA-dominated by
Fig. 6 Principal component scores of groundwater samples in different aquifers

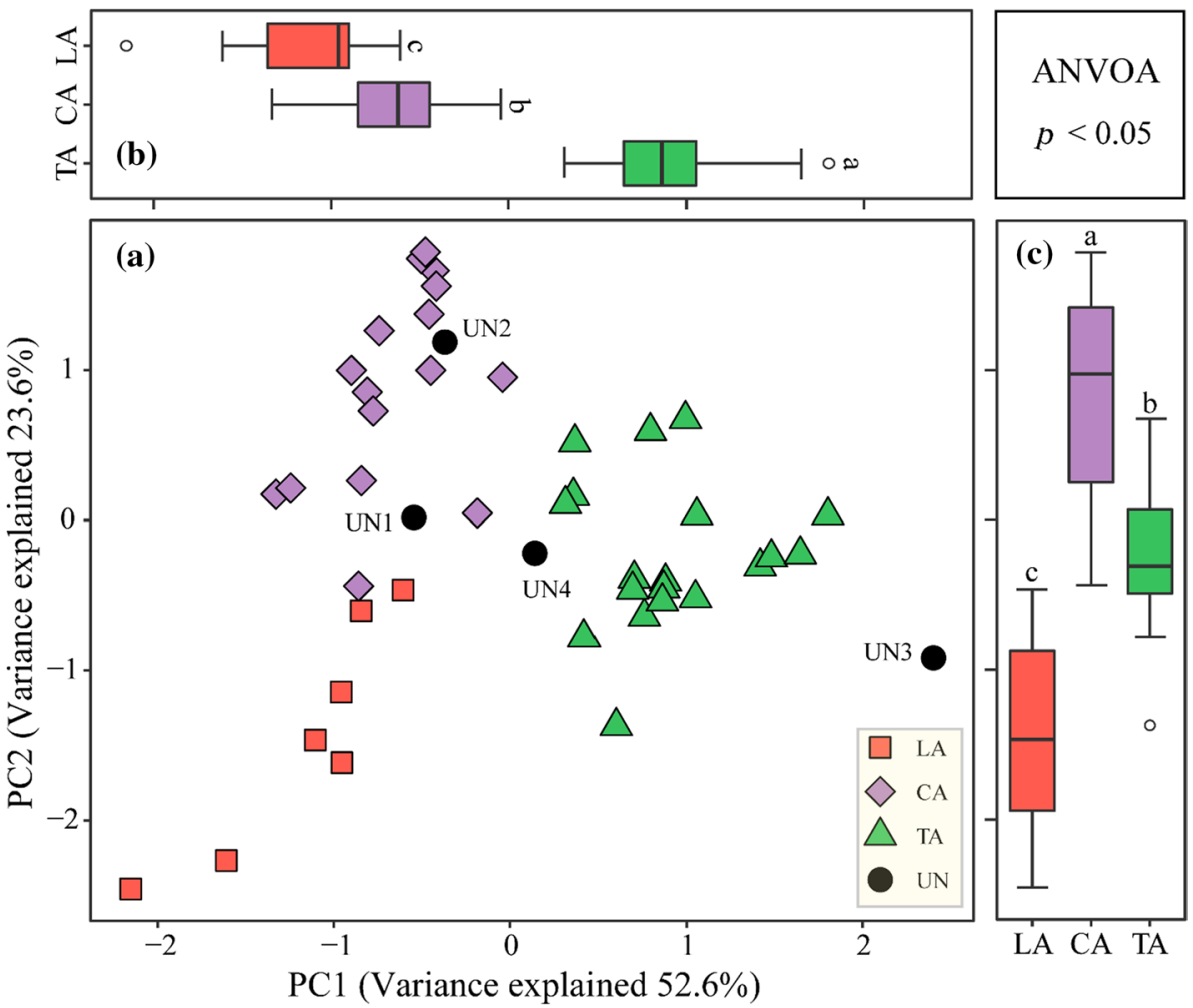


Table 3 Results of principal component analysis

\begin{tabular}{llr}
\hline Species & PC 1 & PC 2 \\
\hline $\mathrm{Na}^{+}+\mathrm{K}^{+}$ & -0.190 & 0.909 \\
$\mathrm{Ca}^{2+}$ & 0.927 & -0.212 \\
$\mathrm{Mg}^{2+}$ & 0.850 & -0.398 \\
$\mathrm{Cl}^{-}$ & 0.623 & 0.500 \\
$\mathrm{SO}_{4}{ }^{2-}$ & 0.875 & 0.273 \\
$\mathrm{HCO}_{3}{ }^{-}$ & -0.619 & -0.253 \\
Eigen value & 3.155 & 1.418 \\
Variance explained (\%) & 52.6 & 23.6 \\
\hline
\end{tabular}

Table 4 Source profiles (mg/l)

\begin{tabular}{lllll}
\hline Species & Source 1 & Source 2 & $\begin{array}{l}\text { Proportion 1 } \\
(\%)\end{array}$ & $\begin{array}{l}\text { Proportion 2 } \\
(\%)\end{array}$ \\
\hline $\mathrm{Na}^{+}+\mathrm{K}^{+}$ & 389 & 72.6 & 84 & 16 \\
$\mathrm{Ca}^{2+}$ & 3.24 & 161 & 2 & 98 \\
$\mathrm{Mg}^{2+}$ & 3.41 & 71.9 & 5 & 95 \\
$\mathrm{Cl}^{-}$ & 109 & 74.1 & 60 & 40 \\
$\mathrm{SO}_{4}{ }^{2-}$ & 509 & 672 & 43 & 57 \\
$\mathrm{HCO}_{3}{ }^{-}$ & 233 & 54.6 & 81 & 19 \\
\hline
\end{tabular}

the weathering of silicates and ion-exchange reaction; TAdominated by the dissolution of chloride and sulfate; LA-low degrees of water-rock interaction relative to the CA and TA.

\section{The Unmix model approach}

Based on the calculation of the Unmix model, two sources have been identified and the results are listed in Table 4 and shown in Fig. 7. As can be seen in Table 4, the two sources have Min Rsq=0.98 and Min Sig/Noise = 3.72, higher than the minimum standard of the model (Min Rsq $>0.8$ and Min Sig/Noise $>2$ ), indicating that the modeling is invalid (Ai et al. 2014). As suggested in the above text, the weathering of silicate minerals, dissolution of carbonate and evaporate minerals are the main processes controlling the groundwater chemistry in the coal mining related strata (Sun and Gui 2015). Therefore, the Source 1 dominated by $\mathrm{Na}^{+}+\mathrm{K}^{+}, \mathrm{HCO}_{3}{ }^{-}$and $\mathrm{Cl}^{-}$should be explained to be the weathering of silicate minerals and dissolution of chloride, and the source 2 dominated by $\mathrm{Ca}^{2+}, \mathrm{Mg}^{2+}$ and $\mathrm{SO}_{4}{ }^{2-}$ can be explained to be the dissolution of evaporate minerals (sulfates). Such considerations can be demonstrated by the contributions of these sources (Fig. 7), as the samples from the LA and CA have highest contributions from the source 1 (>60\%), consistent with the assertion that this aquifer system is richer in elastic rocks (silicate minerals are the main phases) relative to the TA, which was mainly contributed by the source 2 $(>50 \%)$. As to the samples with unknown sources, the UN1 and 2 have high contributions from the source 1 (similar to the LA and CA samples), whereas the UN3 and 4 have high contributions from the source 2 (similar to the TA samples).
Fig. 7 Variations of source contributions. Samples 1-7, 8-23 and 24-42 are the LA, CA and TA samples, respectively, whereas samples and 43-46 are UN samples
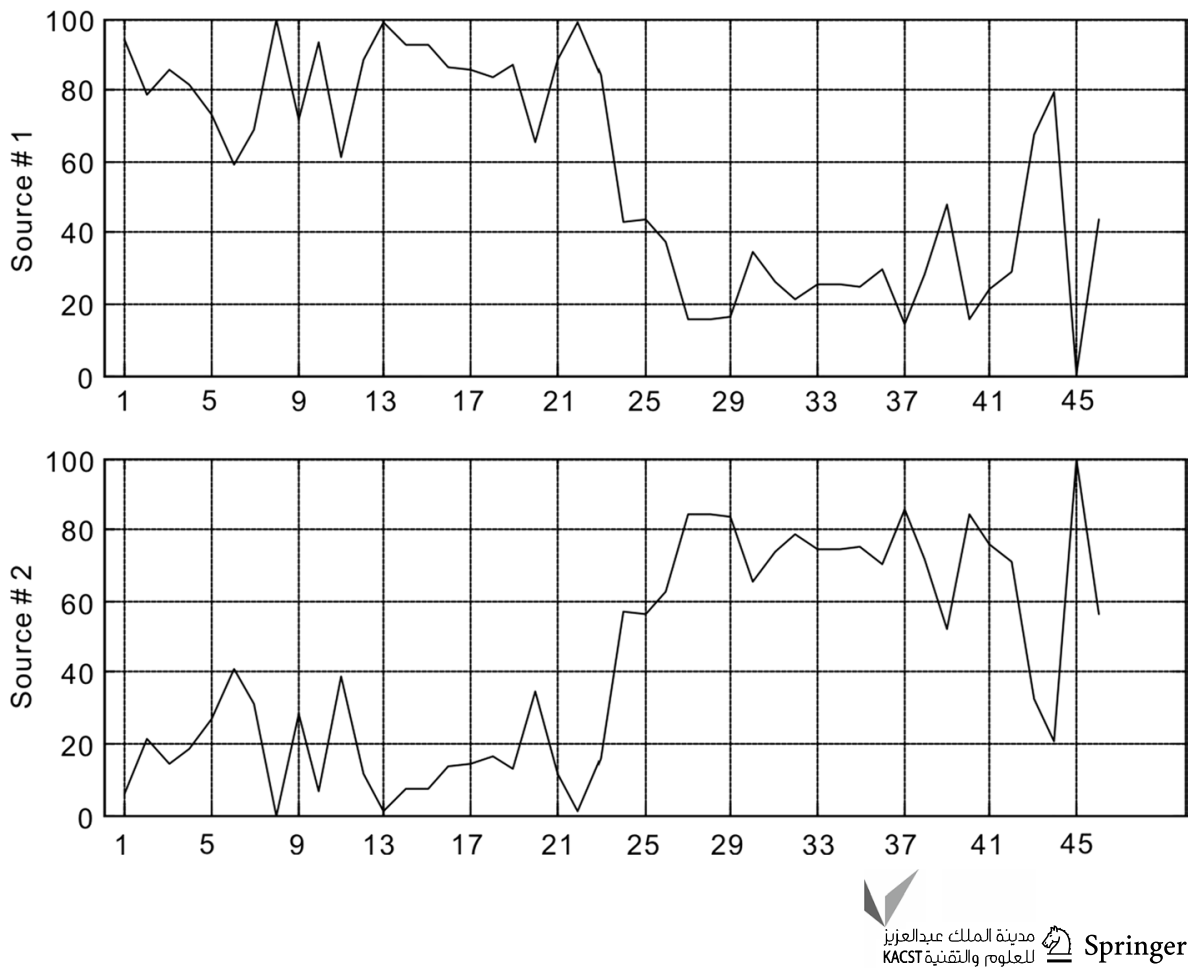


\section{Source identification of inrush water}

\section{Cluster analysis}

In this study, all the samples were analyzed by Q-model cluster analysis and the "Ward" linkage and "Euclidean" distance were chosen to obtain better results (Fovell and Fovell 1993; Liu et al. 2015; Chen et al. 2020). As can be seen from Fig. 8, three groups can be identified: all the samples from the LA and two samples from CA have been classified into the Group 1, and most of the samples from the CA have been classified into the Group 2 (except for the CA4 and CA11), whereas all the TA samples have been classified into the Group 3. Therefore, only two samples (CA4 and CA11) have been classified into the wrong category, and the accuracy rate is $95.7 \%$. It can also be noticed from the figure that the UN1 and UN2 samples are classified to be the Group 2, and the UN3 and UN4 are classified to be the Group 3, similar to the results obtained from the plots of factor scores (Fig. 6) and the variations of source contributions (Fig. 7).

\section{Discriminant analysis}

In this study, the LA, CA and TA groundwater samples are assigned to be 1, 2 and 3, respectively, whereas the UN samples are signed to be "blank." The classical method has been chosen for calculation and the results are shown in Table 5 and shown in Fig. 9. As can be seen from the table, all of the samples with known sources except for one from the
CA (18) have been classified to be the right category with high probability (92-100\%), and the source-known samples have been identified correctly to be $97.6 \%$ (41/42), and the discriminant functions are as follows (unit in $\mathrm{mg} / \mathrm{l}$ ):

1. Function $1=0.001 \times\left(\mathrm{Na}^{+}+\mathrm{K}^{+}\right)+0.002 \times \mathrm{Ca}^{2+}-0.039$ $\times \mathrm{Mg}^{2+}-0.013 \times \mathrm{Cl}^{-}-0.002 \times \mathrm{SO}_{4}{ }^{2-}-0.001 \times \mathrm{HCO}_{3}{ }^{-}$ $+7.120$

2. Function $2=0.011 \times\left(\mathrm{Na}^{+}+\mathrm{K}^{+}\right)-0.001 \times \mathrm{Ca}^{2+}+0.018$ $\times \mathrm{Mg}^{2+}+0.014 \times \mathrm{Cl}^{-}-0.002 \times \mathrm{SO}_{4}{ }^{2-}+0.001 \times \mathrm{HCO}_{3}{ }^{-}$ -7.393 .

Based on the discrimination model established by the known samples, the source of the UN1 and 2 samples are classified to be the CA with $78 \%$ and $100 \%$ probabilities, respectively, and the source of the UN3 and 4 samples are classified to be the TA with $100 \%$ and $87 \%$ probabilities, respectively, similar to the results of cluster analysis.

\section{Conclusions}

Based on the statistical analyses of major ion concentrations of groundwater samples collected from three representative aquifer systems in the Qingdong coal mine, northern Anhui province, China, the following conclusions have been obtained: (1) The major ion concentrations of the groundwater samples from different aquifer systems are different with each other, which suggests that the types and degrees
Fig. 8 Plot of Q-mode cluster analysis

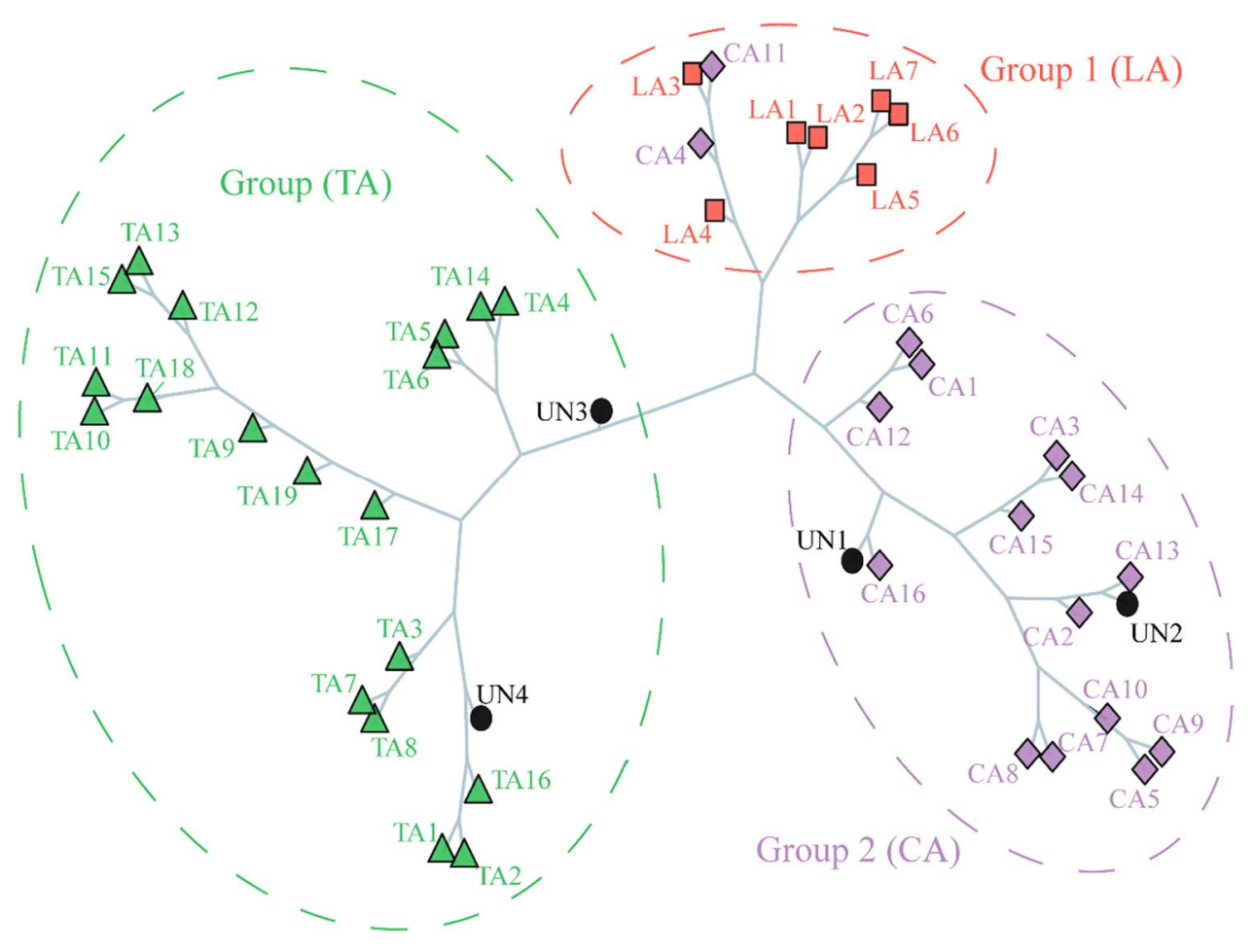

年 KACST للملوم والتقنية 
Table 5 Results of discriminant analysis

\begin{tabular}{llllllll}
\hline ID & Source & Predicted & Probability $(\%)$ & ID & Source & Predicted & Probability $(\%)$ \\
\hline 1 & LA & LA & 100 & 24 & TA & TA & 100 \\
2 & LA & LA & 100 & 25 & TA & TA & 100 \\
3 & LA & LA & 99 & 26 & TA & TA & 100 \\
4 & LA & LA & 100 & 27 & TA & TA & 100 \\
5 & LA & LA & 100 & 28 & TA & TA & 100 \\
6 & LA & LA & 100 & 29 & TA & TA & 100 \\
7 & LA & LA & 100 & 30 & TA & TA & 100 \\
8 & CA & CA & 99 & 31 & TA & TA & 100 \\
9 & CA & CA & 100 & 32 & TA & TA & 100 \\
10 & CA & CA & 100 & 33 & TA & TA & 100 \\
11 & CA & CA & 91 & 34 & TA & TA & 100 \\
12 & CA & CA & 100 & 35 & TA & TA & 100 \\
13 & CA & CA & 100 & 36 & TA & TA & 100 \\
14 & CA & CA & 100 & 37 & TA & TA & 100 \\
15 & CA & CA & 100 & 38 & TA & TA & 100 \\
16 & CA & CA & 100 & 39 & TA & TA & 92 \\
17 & CA & CA & 100 & 40 & TA & TA & 100 \\
18 & CA & LA & 95 & 41 & TA & TA & 100 \\
19 & CA & CA & 100 & 42 & TA & TA & 100 \\
20 & CA & CA & 100 & 43 & UN1 & CA & 78 \\
21 & CA & CA & 100 & 44 & UN2 & CA & 100 \\
22 & CA & CA & 100 & 45 & UN3 & TA & 100 \\
23 & CA & CA & 92 & UN4 & TA & 87 \\
\hline
\end{tabular}

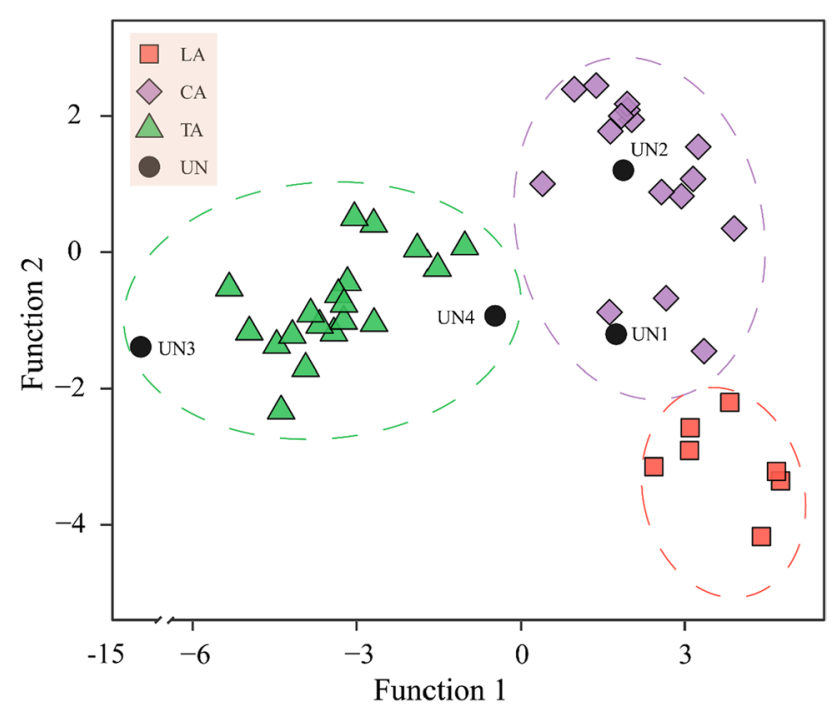

Fig. 9 Discriminant diagram

of water-rock interactions in these three aquifer systems are different. (2) Principal component analysis has identified two sources responsible for the chemical variations of the groundwater: weathering of silicate minerals and dissolution of evaporates, and their contribution ratios for the groundwater samples from different aquifer systems are different with each other, which have been quantified by Unmix model. (3) Based on the Q-mode cluster and discriminant analyses, the samples with known sources have been identified correctly to be $95.7 \%$ and $97.6 \%$, respectively, and the samples with unknown sources have been determined with high probability $(78-100 \%)$.

Acknowledgements This work was financially supported by the Natural Science Research Project of Universities in Anhui Province (KJ2020ZD64 and KJ2020A0740) and the Scientific Foundation of Platform in Suzhou University (2016ykf02).

\section{Compliance with ethical standards}

Conflict of interest The authors have declared no conflict of interest.

Open Access This article is licensed under a Creative Commons Attribution 4.0 International License, which permits use, sharing, adaptation, distribution and reproduction in any medium or format, as long as you give appropriate credit to the original author(s) and the source, provide a link to the Creative Commons licence, and indicate if changes were made. The images or other third party material in this article are included in the article's Creative Commons licence, unless indicated otherwise in a credit line to the material. If material is not included in the article's Creative Commons licence and your intended use is not permitted by statutory regulation or exceeds the permitted use, you will need to obtain permission directly from the copyright holder. To view a copy of this licence, visit http://creativecommons.org/licenses/by/4.0/. 


\section{References}

Ai JC, Wang N, Yang J (2014) Source apportionment of soil heavy metals in Jiapigou goldmine based on the UNMIX model. Environ Sci 35(9):3530-3536

Bencer S, Boudoukha A, Mouni L (2016) Multivariate statistical analysis of the groundwater of Ain Djacer area (Eastern of Algeria). Arab J Geosci 9(4): 1-10

Chen K, Sun LH, Tang J (2020) Hydrochemical differences between river water and groundwater in Suzhou, Northern Anhui Province. China Open Geosci 12(1):1421-1429

Fovell R, Fovell MY (1993) Climate zones of the conterminous United States defined using cluster analysis. J Clim 6(11):2103-2135

Gibbs RJ (1970) Mechanisms controlling world water chemistry. Science 170(3962):1088-1090

Gui HR, Chen LW (2007) Hydrogeochemistric evolution and discrimination of groundwater in mining district. Geological Publishing House, Beijing

Gubran M, Ghrefat H, Zaidi F, Shehata M (2019) Integration of hydrochemical, GIS, and remote-sensing data for assessment of shallow groundwater aquifers in Wadi Nisah, Central Saudi Arabia. Environ Earth Sci 78(5):161

Jain S, Sharma SK, Mandal TK, Saxena M (2018) Source apportionment of PM10 in Delhi, India using PCA/APCS, UNMIX and PMF. Particuology 37:107-118

Lang YH, Yang W (2014) Source apportionment of PAHs using Unmix model for Yantai costal surface sediments, China. Bull Environ Contam Toxicol 92(1):30-35

Liu Q, Sun YJ, Xu ZM, Xu G (2018) Application of the comprehensive identification model in analyzing the source of water inrush. Arab J Geosci 11(9): 189

Liu LL, Wang ZP, Feng J, Zhang T (2015) Co-occurrence correlations of heavy metals in sediments revealed using network analysis. Chemosphere 119:1305-1313

Liu XH, Sun LH (2015) Chemical variations of groundwater in coal bearing aquifer in northern Anhui Province, China: study based on Unmix model and major ions. Electron J Geotech Eng 20(15):6549-6557

Liu Z, Yang H, Cheng W, Ni GH (2017) Stress distribution characteristic analysis and control of coal and gas outburst disaster in a pressure-relief boundary area in protective layer mining. Arab J Geosci 10(16):358

Nordstrom DK, Ball JW, Donahoe RJ, Whittemore D (1989) Groundwater chemistry and water-rock interactions at Stripa. Geochim Cosmochim Acta 53(8):1727-1740

Ramaroson V, Randriantsivery JR, Rajaobelison J, Fareze LP, Rakotomalala CU, Razafitsalama FA, Rasolofonirina M (2020) Nitrate contamination of groundwater in Ambohidrapeto-AntananarivoMadagascar using hydrochemistry and multivariate analysis. Appl Water Sci 10(7):1-13

Shi SS, Xie XK, Bu L, Zhou ZQ (2018) Hazard-based evaluation model of water inrush disaster sources in karst tunnels and its engineering application. Environ Earth Sci 77(4):141

Si LL, Li ZH, Yang YL (2018) Coal permeability evolution with the interaction between nanopore and fracture: Its application in coal mine gas drainage for Qingdong coal mine in Huaibei coalfield, China. J Nat Gas Sci Eng 56:523-535

Sun LH (2013) Hydrochemical variation during groundwater mixing: a case study with multivariate statistical approach. Water Pract Technol 8(3-4):399-408
Sun LH, Gui HR (2015) Hydro-chemical evolution of groundwater and mixing between aquifers: a statistical approach based on major ions. Appl Water Sci 5(1):97-104

Sunkari ED, Abu M (2019) Hydrochemistry with special reference to fluoride contamination in groundwater of the Bongo District, Upper East Region, Ghana. Sustain Water Resour Manag 5(4):1803-1814

Sunkari ED, Abu M, Zango MS, Wani AML (2020) Hydrogeochemical characterization and assessment of groundwater quality in the Kwahu-Bombouaka Group of the Voltaian Supergroup. Ghana J Afr Earth Sci 169:103899

Team, Core R (2013) R: A language and environment for statistical computing. Vienna, Austria. http://www.R-project.org

Tay CK, Hayford E, Hodgson IO, Kortatsi BK (2015) Hydrochemical appraisal of groundwater evolution within the Lower Pra Basin, Ghana: a hierarchical cluster analysis (HCA) approach. Environ Earth Sci 73(7):3579-3591

Tóth J (1999) Groundwater as a geologic agent: an overview of the causes, processes, and manifestations. Hydrogeol J 7(1):1-14

Wang D, Shi LQ (2019) Source identification of mine water inrush: a discussion on the application of hydrochemical method. Arab J Geosci 12(2):58

Wang Y, Shi LQ, Wang M, Liu TH (2020) Hydrochemical analysis and discrimination of mine water source of the Jiaojia gold mine area, China. Environ Earth Sci 79(6):1-14

Wu Q, Mu WP, Xing Y, Qian C, Shen JJ, Wang Y, Zhao DK (2019) Source discrimination of mine water inrush using multiple methods: a case study from the Beiyangzhuang Mine, Northern China. Bull Eng Geol Environ 78(1):469-482

Wu Q, Zhao SQ, Sun WJ, Cui FP, Wu C (2013) Classification of the hydrogeological type of coal mine and analysis of its characteristics in China. J China Coal Soc 38(6):901-905

$\mathrm{Xu} \mathrm{H}, \mathrm{Bu} \mathrm{W}$ (2015) Analysis of water-inrush for deep coal floor in a coal mine. Electron J Geotech Eng 20(10):4189-4196

Yidana SM, Bawoyobie P, Sakyi P, Fynn OF (2018) Evolutionary analysis of groundwater flow: application of multivariate statistical analysis to hydrochemical data in the Densu Basin, Ghana. J Afr Earth Sc 138:167-176

Yu H, Gui HR, Zhao HH, Wang MC, Li J, Fang HX (2020) Hydrochemical characteristics and water quality evaluation of shallow groundwater in Suxian mining area, Huaibei coalfield, China. Int J Coal Sci Technol 12:1-11

Zango MS, Sunkari ED, Abu M, Lermi A (2019) Hydrogeochemical controls and human health risk assessment of groundwater fluoride and boron in the semi-arid North East region of Ghana. J Geochem Explor 207:106363

Zhang J, Li RF, Zhang XY, Bai Y, Cao P, Hua P (2019) Vehicular contribution of PAHs in size dependent road dust: a source apportionment by PCA-MLR, PMF, and Unmix receptor models. Sci Total Environ 649:1314-1322

Publisher's Note Springer Nature remains neutral with regard to jurisdictional claims in published maps and institutional affiliations. 